Anderson, R. K., Robinson, W. D., Calvo J. \& Payne G. C. (1946). F. Amer. diet. Ass. $22,588$.

Anonymous (1945). Misc. Publ. U.S. Dep. Agric. no. 572.

Armstrong, E. F. \& Armstrong, K. F. (193I). The Glycosides. London: Longmans Green.

Aylward, F. (195 r). Nature, Lond., 168, 1100.

Calvo, J., Serrano, G., Millan, R. S., Miranda, F. de P. \& Anderson, R. K. (1946). F. Amer. diet. Ass. 22, 297.

Chase, S. (1931). Mexico, A Study of Two Americas. London : Macmillan and Co.

Chatfield, C. \& Adams, G. (1940). Circ. U.S. Dep. Agric. no. 549.

Cravioto, R. B., Anderson, R. K., Lockhart, E. E., Miranda, F. de P. \& Harris, R. S. (1945). Science, I02, $9 \mathrm{r}$.

Cravioto, R. B., Lockhart, E. E., Anderson, R. K., Miranda, F. de P. \& Harris, R. S. (1945). $\mathcal{F}$. Nutr. 29, 317.

Dunstan, W. R., Henry, T. A. \& Auld, S. J. M. (1906). Proc. roy. Soc. B. 78, I52.

Harris, R. S. (1945). Science, ro2, 42 .

Harris, R. S. (1946). F. Amer. diet. Ass. 22, 974.

Harris, R. S. (1948). Nutr. Rev. 6, 33.

Harris, R. S. (1952). Int. Z. Vitaminforsch. 23, 405.

Harris, R. S. \& Munsell, H. E. (1950). F. Home Econ. 42, 629.

Hill A. F. (I937). Economic Botany. London : McGraw Hill Book Co.

Lockhart, E. E., Miranda, F. de P. \& Harris, R. S. (1946). Fed. Proc. 5, 235.

Mason, G. (193I). Columbus Came Late. London: The Century Co.

Munsell H. E., Williams, L. O., Guild, L. P., Kelley, L. T. \& Harris, R S (1950). Food Res, I5, 42r.

Munsell H. E., Williams, L. O., Guild, L. P., Kelley, L. T., McNally A. M. \& Harris, R. S. (I950). Food Res. 15, 379.

Munsell, H. E., Williams, L. O., Guild, L. P., Kelley, L. T., McNally, A. M. \& Harris, R. S. (1950b). Food Res. 15, 439.

Munsell, H. E., Williams, L. O., Guild, L. P., Troescher, C. B. \& Harris, R. S. (1950). Food Res. I5, 355 .

Munsell, H. E., Williams, L. O., Guild, L. P., Troescher, C. B., Nightingale, G. \& Harris, R. S. (I949) Food Res. 14, 144.

Munsell, H. E., Williams, L. O., Guild, L. P., Troescher, C. B., Nightingale, G. \& Harris, R. S. (I950a). Food Res. 15, 16.

Munsell, H. E., Williams, L. O., Guild, L. P., Troescher, C. B., Nightingale, G. \& Harris, R. S. (1950b). Food Res. $15,34$.

Munsell, H. E., Williams, L. O., Guild, L. P., Troescher, C. B., Nightingale, C., Kelley, L. T. \& Harris, R. S. (1950). Food Res. 15, 263.

National Research Council (1945). Rep. Nat. Res. Coun., Wash., no. 122.

Prescott, R. (1949). Conquest of Mexico. London : Allen \& Unwin.

Robinson, W. D., Payne, G. C. \& Calvo, J. (1944). F. Amer. diet. Ass. 20, 289.

Vaillant ,G. C., (1950). The Aztecs of Mexico. London : Penguin Books Ltd.

Winton, A. L. \& Winton, K. B. (1932). The Structure and Composition of Foods, Vol. I. London : Chapman \& Hall Ltd.

\title{
The Food of the Australian Aboriginal
}

\author{
By G. H. Bourne, Department of Histology, \\ London Hospital Medical College, Turner Street, London, E.I.
}

The Australian aboriginal is, at least from a cultural point of view, a stone-age man. That is to say, he is a nomadic hunter and makes no attempt to cultivate the ground and to make permanent camps or settlements in any one place.

A tribe will occupy an area of country until it is denuded of food and will then move on to a fresh region. In some areas food may be so plentiful that a tribe may remain there for some considerable time. 
Since the advent of the white man and his establishment of sheep and cattle stations and of missions, groups of natives have tended to camp in the neighbourhood of such settlements. Some were employed on the stations and were given mainly food in return for their labour. This food consisted largely of white flour and sugar. That was the sort of food which the missions also were most prone to give to the natives. When the natives had exhausted the natural foods in the neighbourhood of the missions and stations they tended to remain in the vicinity and attempted to exist on these high-energy, low-vitamin foods and as a result developed in many instances multiple vitamin and possibly mineral deficiencies. In this way the aboriginals of the area were sometimes virtually wiped out. Movement of missions to new areas resulted in a repetition of the process. It is of interest that the natives believed that half-castes were due to the consumption by the women of the tribe of white flour ; sexual relations with white men were not thought of as a cause.

During $195 \mathrm{I}$ the Australian Government authorized an investigation into the diets of natives living in contact with white people (Commonwealth Department of Health (Australia) I95I). The diets were investigated for calories, protein, calcium, iron, vitamin $\mathrm{A}$, thiamine and ascorbic acid. It was found that in general they were adequate in calories, protein, iron and thiamine. Many, however, were deficient in calcium, vitamin $A$ and ascorbic acid. The Government then recommended the type and amount of various foodstuffs for issue to natives. Among the general recommendations was that liver and kidneys on stations, instead of being fed to poultry, should be given to natives.

In view of the deterioration of the diet of the aboriginals when in contact with white man it becomes of special interest to investigate the foodstuffs consumed by man in his wild state. No comprehensive survey of the nutritional value of these wild foods has ever been carried out although I believe some limited analyses of some foods have been made, and it would be an extremely interesting and valuable piece of research for someone in Australia to do. It is very difficult to assess the nutritional level of the aboriginal diet because it is so inconstant, varying from day to day and from season to season and also according to the geographical position of the tribe ; the coast-dwelling natives have a different diet from those of the interior. Even tribes of the interior vary from each other in what they eat.

There are few creatures in the animal world which the Australian aboriginal does not use for food, but a more limited number of vegetable substances seems to be eaten.

The men are concerned only in the hunting of large mammals or of animals that require special skill or knowledge to find. Women collect plants and animals that can be obtained by hand work such as digging, e.g. wombats, lizards, snakes and snails.

\section{Mammals}

\section{Composition of the diet}

Animals hunted. The indigenous animals, various sorts of marsupials such as kangaroos, opossums and wallabies, and the echidna (a pro-mammal), were the 
principal game but with the introduction of dingo, rabbit and buffalo new sources of food became available. In 1828 , according to Basedow (1925), when the military settlement at Fort Dundas in the north was disbanded, the Governor, Sir Gordon Bremer let a number of Timor buffaloes which had been used by residents roam at large. These multiplied into thousands. The natives kill them but do not like the flesh as much as that of native game and sometimes kill a buffalo just to eat its tongue or perhaps some of the internal organs. A sea mammal, the Dugong (sea-cow), is also used for food. When full-grown it may measure $12 \mathrm{ft}$. or more in length and weigh $1500 \mathrm{lb}$. It is a vegetarian creature living on algae. At intervals it rises to the surface to breathe and the blowing can be heard a great distance off. The natives hunt the animal in canoes and when it comes up to breathe it may be beyond reach of a spear ; the hunters remain motionless until it disappears again and eventually it may come within spearing or harpooning distance. The harpoon is attached to a rope. The animal dives on being harpooned and the canoe is pulled along at some speed. As soon as the wounded animal comes up for air it is harpooned again, and so on until it is greatly weakened, whereupon the hunters hold its head under water until it drowns. The flesh is greatly prized and that of the pregnant cow is prized most of all (for further details see Basedow, 1925).

Kangaroos are hunted by stalking while the animal is feeding. It is incredible how a native can get to within spearing distance (maximum $20 \mathrm{yd}$.) on a plain almost devoid of cover. The hunter aims to damage the muscles of the hind legs to incapacitate the animal.

Wallabies are caught by ambush along one of their tracks and they and other marsupials may also be caught by digging a hole, covering it with earth and putting a $\log$ in front to force the animal to jump high and land heavily on and break through the thin roof of the hole, when it is quickly despatched by a hiding native.

Elaborate customs decide about what part of a carcass goes to whom and vary with the tribe. If a number of people catch an animal there is an official cutter-up who helps himself to the kidneys and the heart. If a kangaroo, however, is killed by an unmarried man assisted by a married man, everything goes to the wife's parents except the left hind-leg, which goes to the brother and the right hind-leg which goes to the unmarried man. Some animals are shared between everybody. If a married man catches an emu, he eats the intestines, liver and gizzard, the legs go to his wife's father, and the body is shared by his own parents.

Methods of cooking. Larger mammals are cooked in a depression of the ground. The opossum and small wallaby, for example, are disembowelled, the fur is plucked off and the body placed in hot ashes. When they are partly cooked incisions are made in the muscles of these animals and the fluid with which they fill is scooped out and drunk. This fluid is greatly liked.

In cooking the echidna the intestines are first removed and the animal is placed in a small hole dug in the ground and filled with water. The back is covered with a layer of moist earth or sand which is removed after $15 \mathrm{~min}$ and hot ashes substituted. The animal is removed after a few minutes and the skin with the quills is 
cut off with a flint and the body is then placed back in the hot ashes to cook. With larger animals such as the kangaroo, the intestines are removed and the body cavity closed with wooden skewers. The tendons are also removed and used for a variety of purposes. The intestines are cooked by rolling about in hot ashes and any fat is carefully removed, as according to Basedow (1925) it is regarded as a great delicacy. A large fire is made in a hole and as it burns down the animal is put into the hole and hot ashes are heaped over it. It is allowed to cook for $\mathrm{I}_{5} \mathrm{~min}$.

\section{Reptiles}

Lizards, snakes, crocodiles and turtles and their eggs are all eaten. Snakes and lizards figure in most meals. To kill them they are tracked to their holes and dug out. The natives may set fire to patches of country and kill snakes and lizards as they are driven out. Those caught by the fire and partly roasted are collected when the ground has cooled.

The most popular lizards are two species of Varanus known locally as the printhy and the goanna. In central and north Australia these may grow very big ; the printhy, for example, may reach $6 \mathrm{ft}$. in length. Goanna fat according to Basedow ( 1925 ) is prized as a nutriment, as a medicine and as a cosmetic ointment.

The method of capturing the turtle is of interest (see Basedow). When the turtle is seen floating on the surface of the water all the natives nearby keep quiet and the fishers' canoe is paddled gently towards it. At a reasonable distance two men slip into the water silently and swim under water towards the turtle. Nearer still two or three more jump in and make a lot of splashing and noise. The turtle puts its head under water preparing to dive, but one of the men under water grabs the neck and forces the head above water again. This prevents diving; then one of the other men grabs the turtle by the rim of the shell at the back of the neck and pulls on it, this puts a slope on the turtle and as it furiously paddles its movements tend to force it out of the water. If the turtle is a big one the native may sit on its back. The turtle is then dispatched by a blow on the head. The female turtle is greatly liked, particularly for its ovaries which are said to look like bunches of yellow dates.

Crocodiles are sometimes caught by a line of men moving through muddy water to frighten the animals and drive them on to land where they are quickly killed.

\section{Amphibia}

Frogs are collected mainly by women. A type of frog which stores large quantities of water in its lymph spaces is sought when water is scarce. These frogs bury themselves in a dried-up water-hole from which they are dug out. They are put in the mouth and bitten and the water is consumed, then the rest of the frog is thrown away.

\section{Fish}

Many sea fish are consumed by the coastal tribes and the northern tribes eat river fish. Many water holes left along the courses of partly dried-up rivers also 
have fish trapped in them. Such fish are caught by a group of men who drive them into shallow water, catch them and throw them on land. Here they are picked up by the gins (women) who kill them by.putting their heads in their mouths and crushing them with their teeth. The natives also catch fish by filtering the water of small streams through brush-wood filters and by building barriers across narrow sea inlets, so that when the tide recedes fish are left behind. Fish may also be caught by leaving nooses in position in the water, by spearing or netting them. Some tribes use a hook and line, the hooks being made of bone or pearl shell.

\section{Birds}

The emu is popular as food but is difficult to catch because of its remarkable speed. The natives sometimes dress up in feathers with a pole and a head on top to represent the long neck of the bird. Sometimes they simply carry a bunch of feathers. When they approach the bird they move with sharp jerky bird-like movements and when close enough they spear their quarry.

Another method of catching the birds is to soak the plant Duboisia hopwoodi in the water hole that they visit. The alkaloids of the plant diffuse into the water and stupefy the bird when it drinks.

Many other birds are eaten. These include turkeys, ducks, pigeons, cockatoos, black swans, geese, honey-eaters, hawks and doves. The eggs and the fledglings of all these species are also eaten.

Eggs are cooked by placing on hot ashes and turning frequently to ensure even cooking. In some tribes the cooks snatch hot eggs out of the ashes, spin them in the air to stir up the contents, catch them as they come down and replace them in the ashes.

\section{Invertebrates}

Crabs and crayfish and oysters are of course consumed by the coastal tribes. Mussels (Unio) are also eaten by those living near rivers. Enormous piles of mussel shell have been found near the larger rivers. The coastal tribes of course eat almost every type of marine mollusc including the coiled periwinkle types, gastropods, and many varieties of bivalves resembling cockles.

Larger forms of land snails are eaten, particularly by inland tribes. After rain the snails may come out in large numbers and are collected by the women. The principal species is Helix perinflata. Even in summer in some parts of central Australia a meal of snails can always be found by searching under tussocks and stones. Snails are eaten by throwing them on hot ashes and then picking out the animal with a sharp stick.

The pupas of ants represent another staple food and white ants are mixed with ground seeds and baked. Some types of moth are also very popular and when roasted taste like unpeeled almonds.

In some parts of the country the natives periodically feast on moths. A fire is lit at night and as the moths are attracted they are thrown into the hot ashes and then consumed. Their juice is described as being of rich yellow colour. These feasts probably provide abundant vitamin $A$. 
Many caterpillars, particularly the green ones, are popular. They are flung into the hot ashes until they straighten out by which time the hairs are also singed off, and the animal is eaten. Many forms of larva are eaten ; most widespread and most popular is the larva of the big Cossus moth, known as the Witchedy grub. There are two varieties of this grub ; one variety lives in the roots of the acacia and another in the butt of eucalyptus trees. The grub is extracted from its hiding place, usually a long tunnel in the wood, by inserting a hooked stick. The flavour of this grub is said to resemble slightly sweetened scrambled egg.

The honey of wild bees is eaten with relish. It is known as 'honey bag' and every native is constantly on the look-out for such a delicacy.

One way used by the natives for discovering a hive is to catch a bee and attach a piece of fluff to it to make it easily visible, then to follow it. Some of the more experienced hunters are said to be able to smell their way to hives of wild bees from a considerable distance. Fortunately for the natives the wild bee has no sting. Their hives are usually in a hollow tree or a crevice in the ground and the native lifts the comb out and immediately begins to suck it. In a hollow tree a native can gauge fairly accurately the position of a hive by applying his ear to different parts of the tree. When hives are in inaccessible fissures a bundle of vegetable fibre or bark is tied to a long stick which is plunged into the comb and then withdrawn. The attached honey is squeezed out into a receptacle.

In central Australia there are no wild bees but the substitute is the honey ant, Melophorus inflatus. These animals live underground in red sandy loams. Sometimes the natives have to dig to considerable depths to get at the nest. The honey ant is a modified worker that has been so overfed by ordinary workers that its abdomen swells to the size of a marble $\left(\frac{3}{8}\right.$ in. diameter). The abdominal wall (with the exception of a few small plates of chitin) is reduced to a thin membrane through which honey can be seen, and the insect's viscera are squeezed into a small space near the vent. In this condition the ants are quite immobile and are therefore, as Basedow (1925) says, like living tanks or barrels of honey, tapped as required in the poor season. When the ant is eaten it is gripped by the head, the abdomen is placed between the lips and the honey is squeezed out into the mouth. The first sensation is said to be a prick due to formic acid, and the honey is said to have a delicious and rich flavour. This honey and that of wild bees is much more liquid than the cultivated honey of western countries.

Another very popular insect product is lerp manna. These are white conical structures about the size of a lentil found on leaves of red gums (Eucalyptus rostrata) They are secreted by larvas of an insect known as Psylla and are sweet in taste.

\section{Vegetables}

According to Basedow (1925) the commonest vegetables are the corms of Cyperus rotundus which grows in sandy banks of nearly all river courses in certain areas. A tribe may turn over a considerable area of soil in search of these corms. They are small, only the size of a field pea. They are rubbed between the hands 
(to remove the light shell) and eaten raw. They have a sweet, rather nutty, flavour and are sometimes eaten roasted in hot ashes.

The small black seeds of the munyeroo (a species of Claytonia) are collected in large numbers, ground on a stone, reduced to a mealy consistency and made into a paste with water. They may then be eaten in this way or baked in cakes. Nardoo, consists of the spore cases of a cryptogramous plant (Marsilea quadrifolia) (Sollas, I924). The spore cases are ground and baked. The Burke and Wills expedition into central Australia is said to have starved on nardoo, but the main deficiency from which they suffered was lack of ascorbic acid and it was scurvy that brought disaster in the end (Beckler, 1865).

Acacia seeds and the bark of some species of mallee tree are also used for food. The bark is ground, mixed with white ants and baked as a cake. The pods of acacia are laid on hot ashes and the natives sit around and shell and eat the seeds rather like shelling peas. The seeds of the lotus lily are ground and baked and the tuber of the water lily, roasted in ashes, is said to taste like a potato with a flavour similar to a Jerusalem artichoke.

The yam, of which there are many varieties, is the most popular tuber dish. Some yams are so hot that according to Basedow (I925) they blister the mucous membranes of the mouth if a small piece is applied to the skin. The natives are expert in telling by sight which they can and which they cannot eat. Some are not eaten because they cause what the natives describe as 'painful fire in the anus'.

Truffles (a species of Scleroderma) are found in some parts of the country and, according to Basedow, are like the European truffle. A creeper called Marsdenia leichhardi is common in some regions. It has a pear-shaped fruit (native pear) and a thick milky sap. The fruit, stalks and leaves are eaten and have an agreeable sweetish taste.

Gall-nuts and excrescences found on various trees are also favoured. Basedow says that the most popular one is found on the twigs of the mulga tree and is referred to by whites as the 'mulga apple'. It is about the size of a walnut and the whole is eaten, including the insect causing the gall. The gall is rather tasteless but with a slight flavour of eucalyptus. The 'bloodwood apple' is a gall found on bloodwood (Eucalyptus corymbosa). The inside is hollow and contains the parasite and a sweetish juice. The inner layer of the shell is white, soft and edible. There is also an edible berry known as the quondong or native peach.

The seeds of the bunya bunya tree (a giant Araucaria) are eaten at the appropriate season of the year. Bunya feasts are then held and may last a month.

A form of arrowroot is made from a plant called the Wangoora (a species of Ipomoea). This has a poisonous bitter principle in its roots which is washed away with water when the roots are crushed, leaving the starch behind. Some species of Malayan cassava have a similar principle which is removed in the same way.

\section{Beverages}

The principal beverage is water. In emergencies the roots of some trees are cut out and set against the trunk of the tree to drain. A quart of water is said to be 
obtained from Ioft. of root, 2 or 3 in. in diameter. Sometimes Eremophila (honeysuckle) flowers are stirred in water to give it a slightly sweetish taste. Nectar also is obtained from the beautiful red flowers of Brachysema chambersii, which Basedow says grow abundantly in sandhills north and south of the MacDonnell Ranges. Wild-bee honey may also be disolved in water for sweetening purposes.

The large fruits of the corkscrew palm (Pandanus) are sometimes crushed between heavy stones and immersed in water for some time. The juice is sweetly astringent and is said to produce a refreshing toddy. If it is kept for some time fermentation takes place and on great festive occasions natives may make themselves merry with this drink, but it is not very potent. They do not often make intoxicating drink.

\section{Food taboos}

There are many taboos concerning the eating of food, a few examples of which are given below.

Tribes bear the totem names of various animals and some tribes are not allowed to eat the flesh of the animal whose totem name they bear. In one tribe a weakly child was given the flesh of a strong one with the idea of strengthening him. The Australian aboriginal, however, is not a cannibal in the accepted sense of the term.

Expectant mothers in some tribes are not allowed to eat certain birds, snakes or grubs, and boys are not allowed to eat goannas (lizards) caught by day.

In some tribes after a boy has passed through the initiation ceremony a large number of foods is barred to him, possibly for some years. Thus, he may not be allowed certain roots, lizards, snakes, birds, marsupials and eggs but, on the other hand, he is allowed lily seeds, certain roots, honey, male opossums, male turtles, crocodiles, baramunda fish, catfish and pigeons, ducks and geese and their eggs.

In another tribe no young girl may eat turkey, kangaroo, turtle or turtle eggs unless given to her by a young man.

Many of the foods eaten by the Australian aboriginal are eaten in other parts of the world. Oysters and mussels, clams and snails have been and are universally eaten. Insects, both larvas and adults are also widely eaten and the honey ant has for many centuries been eaten by the Mexican Indian. Locusts are eaten all across the East from the Mediterranean to the Phillipine islands. Squid and sea-urchin, bêche-de-mer, birds'-nest soup, are all consumed where and when they may be obtained. South-sea islanders have feasts of the palolo worm which swarms in the South Seas at a precise time every year.

\section{REFERENCES}

Basedow, H. (1925). The Australian Aboriginal. Adelaide : F. W. Preece and Sons.

Beckler, H. (1865). Verh. berl. med. Ges. I 2 II.

Commonwealth Department of Health (Australia) (195I). Provisional Ration Scales for the Feeding of Aboriginals. Canberra : Government Printer.

Sollas, W. J. ( I924). Ancient Hunters, London; Macmillan and Co. 